\title{
Expanding the Powers of a Specialist in Pre-Trial Proceedings as a Necessary Condition for Improving the Quality of Investigative Actions Aimed at Obtaining Testimony
}

\author{
Alexander I. Bayanova, Larisa P. Klimovich ${ }^{a}$ \\ and Nikolay G. Stoyko b* \\ ${ }^{a}$ Siberian Federal University \\ Krasnoyarsk, Russian Federation \\ ${ }^{b}$ Saint-Petersburg State University \\ Saint-Petersburg, Russian Federation
}

Received 08.08.2020, received in revised form 31.08.2020, accepted 29.09.2020

\begin{abstract}
Based on the analysis of domestic historical experience and the current state of the legislative regulation of the involvement of a specialist to assist an investigator in investigative proceedings, as well as the survey of investigators, it is concluded that it is necessary to expand the powers of a specialist in terms of rendering assistance to an investigator during investigative actions aimed at obtaining testimony (including interrogation). In this regard, proposals to amend the wording of Articles 38 and 58 of the Criminal Procedure Code of the Russian Federation are made. The proposed changes will significantly expand the powers of a specialist in the course of all investigative actions (including verbal ones) and will correspond to the modern trends in the development of criminal proceedings, increasing its quality by attracting specific knowledge and skills from various fields of human activity.
\end{abstract}

Keywords: investigative action, investigator, specialist, collection of evidence, assistance to investigator.

Research area: criminal procedure.

Citation: Bayanov, A.I., Klimovich, L.P., Stoyko, N.G. (2020). Expanding the powers of a specialist in pre-trial proceedings as a necessary condition for improving the quality of investigative actions aimed at obtaining testimony. J. Sib. Fed. Univ. Humanit. Soc. Sci., 13(10), 1652-1661. DOI: 10.17516/19971370-0671.

\footnotetext{
(C) Siberian Federal University. All rights reserved

* Corresponding author E-mail address: bayanov1603@yandex.ru, klimovichl@mail.ru, nstoiko@mail.ru ORCID: 0000-0003-0297-213X (Bayanov); 0000-0001-5044-8397 (Klimovich); 0000-0002-4523-7816 (Stoyko)
} 


\section{Introduction}

Issues related to the participation of a specialist in criminal proceedings during investigative actions have always been and are still within the scope of interest of the legislator, legal science and practice.

The current interest in these issues can be explained by a number of objective factors. Firstly, by constant changes in the existing regulatory framework, the adoption of new and improvement of the existing legal acts regulating relations between power structures, business entities and other persons; secondly, by the presence of contradictions between regulatory prescriptions and relations between its individual subjects arising in a particular sphere of activity; thirdly, by the emergence of not only new methods, but whole technologies based on modern achievements of science and technology, aimed at the implementation of criminal intents and concealment of their consequences (when using the existing problems in the legislative framework and drawbacks in the activities of law enforcement agencies). These factors require the use of a wide variety of highly specialised knowledge, skills and abilities in the investigation process, which a modern investigator or interrogator (even with significant work experience) simply cannot master. An investigator or interrogator must be an expert in law, its interpretation and application (within the scope necessary for carrying out criminal proceedings), as well as a specialist with forensic scientific knowledge (within the scope necessary for mastering the methods of criminal investigation and the tactics of performing certain procedural and investigative actions).

As for the use of highly specialised knowledge and skills from other areas of professional activity and various fields of science and technology in the investigation process, it should be noted that it started to be carried out at a systematic (more or less organised) level in the $19^{\text {th }}$ century (it was associated with the emergence of the forensic science). In the end, this led to the consolidation of the participation of the so-called "competent persons" in criminal proceedings, who have specialised information and experience in science, art, craft, or in any occupation (Article 112, Article 1160 of the SCP) in the Statute of Criminal Procedure (SCP) of the Russian State in 1864'. Competent persons were prototypes of modern specialists and experts and were involved into such procedural actions as inspection, examination, and search (Article 114 of the SCP), which are now commonly referred to as non-verbal investigative actions. Thus, the main emphasis in the participation of competent persons in procedural actions was aimed on the study of material sources of evidence (the scene of incident/ search, human body, corpse, documents, etc.).

However, one cannot but pay attention to the explanations to the Article 692 of the SCP which concerned the participation of an expert in the process of a witness interrogation. According to these explanations, despite the absence of a corresponding "permission" in the legal norms, it was allowed for an expert to ask witnesses in the case questions when it was necessary to give a "correct opinion" (Shramchenko et al., 1911: 654).

The presence of this clarification indicates that the real needs of practical activity were beyond the frames of the formal rules of the law.

In the Soviet period (in 1966), Article $1331^{1}$ was introduced into the Criminal Procedure Code of the RSFSR, which was later amended to clarify the role of a specialist in investigative actions. The introduction of this norm into the Criminal Procedure Code of the RSFSR was undoubtedly a step forward. But it was a halfstep which did not meet the demands of investigative practice. The participation of a specialist, as it was before, was limited to assisting the investigation in the discovery, consolidation, and seizure of evidence. As for the involvement of a specialist to assist an investigator in obtaining full and truthful testimony through verbal investigative actions, this gap was not eliminated. Some participants of the All-Union Research-to-Practice Conference "Introduction of Scientific and Technical Means and Scientific Recommendations into the Practice of Investigation and Trial Proceedings of Criminal Cases" (November 1977) drew attention to this circumstance, offering to legislatively expand

\footnotetext{
Statute of Criminal Procedure of November 20, 1864. Available at: http://base.garant.ru/57791498/
} 
and propagate the use of highly specialised knowledge and skills not only for non-verbal investigative actions, but for interrogations and confrontations as well (Smyk, 1979: 35-36). It should be noted that such proposals were not included into the final document of the conference. It took several decades for the domestic legislator to secure a specialist's right to pose questions to the participants of investigative actions with the consent of an investigator, interrogator and the court (Paragraph 2, Part 3 of Article 58 of the Criminal Procedure Code of the Russian Federation) after the appearance of Article $133^{1}$ in the Criminal Procedure Code of the RSFSR. This decision, however, is also a half-measure and does not correspond to the real needs of investigative practice.

In our opinion, the tasks solved by the modern investigative practice require the expansion of a specialist powers in conducting verbal investigative actions (first of all, interrogation) aimed at obtaining statements concerning highly specialised knowledge in cases where an investigator, for objective reasons, is not able to independently, quickly and without the help of a specialist, correctly formulate questions addressed to an interrogated person, who is also a specialist in a certain area of science and technology and surpasses an investigator in highly specialised knowledge. More significant difficulties can arise in the disclosure of material evidence, testimony of other persons, expert's opinions and assessment of the explanations received, when a quick reaction of an interrogator is required. In such situations, it is reasonable to entrust a specialist to conduct a part of the interrogation independently, without each time addressing an investigator for a permission when posing certain questions aimed at obtaining testimony regarding specific circumstances of an event under investigation.

The issue of what circumstances of an event under investigation will be clarified by an investigator during the interrogation process, and the clarification of which circumstances an investigator can entrust a specialist, is decided before the start of the investigative action and is reflected in the plan of its conduct. In this case, an investigator remains the head of the investigative action and bears personal respon- sibility for its course and results (as well as for the course and results of the entire preliminary investigation).

A similar independence of a specialist during non-verbal investigative actions (inspection, search, seizure, etc.) became the norm a long time ago and leads to positive results. The independence of a specialist during an inspection of the scene of an incident, a search, etc., when a specialist choses the necessary technical means and materials, uses techniques and methods of working with carriers of evidence in the process of finding, securing and seizing material objects and traces (Ugolovnyi protsess Rossii, 2005: 125-126; etc.) does not raise any questions. An investigator fully trusts a specialist to carry out this work, guided by the provision of Part 1, Article 58 of the Criminal Procedure Code of the Russian Federation and the requirement of reasonability in the distribution of duties between the investigative action participants. A similar approach should obviously be used when conducting investigative actions aimed at obtaining testimony, which purpose is not only truthful, but also complete testimony connected with the issues of highly specialised knowledge.

Legislation and judicial practice of, probably, all countries of the world distinguish (similar to Russia) two persons whose specialised knowledge is used in criminal procedure: an expert and a specialist (according to the Russian terminology). Their roles differ significantly. An expert carries out forensic examination and submits its results in the form of a written opinion (or testimony) to an investigative body (or court) ${ }^{2}$. A specialist provides an investigative body (or court) an assistance in investigative action (or judicial inquiry) ${ }^{3}$.

\footnotetext{
2 In common law countries, a written opinion of an expert does not have the value of evidence. The results of the examinations conducted on the initiative of the parties are presented to the court by giving testimony. These and other features of conducting expert examinations in criminal cases in common and continental law countries are revealed in a number of studies by Russian and foreign scientists (Beulke, 2004; Shepherd, 1993: 817-818; Nogel, 2019: 20; Friis, Åström, 2017: 64; Narang, Paul, 2017; Kurs ugolovnogo protsessa, 2017: 501-506). 3 It should be noted that in Russia a specialist is also a person who, at the initiative of the defence, can conduct expert examinations and give written opinions or express his/her opinion on special issues in writing (opinion) or orally (testimony) to
} 
At the same time, the target orientation of a specialist's activity, as a rule, is solely and exclusively related to the detection, consolidation and seizure of traces, objects, documents and the use of technical means during the procedural action carried out by an investigation body (see, for example, Article 84 of the Criminal Procedure Code of the Republic of Armenia, Article 62 of the Criminal Procedure Code of the Republic of Belarus, Article 80 of the Criminal Procedure Code of the Republic of Kazakhstan, Article 111.1 of the Criminal Procedure Code of the Republic of Estonia). Along with that, there is another entirely unusual approach, when a specialist is empowered to carry out the entire investigative action on his/her own. In this way, Article 205 of the Criminal Procedure Code of the Republic of Lithuania provides a specialist with an opportunity to inspect the scene of an incident. ${ }^{4}$

Thus, there is a problem that is expressed in the lack of certainty of the position of a specialist in investigative proceedings (non-verbal actions, mainly at the level of law, and verbal (aimed at obtaining testimony) - at the level of law and practice).

\section{Statement of the problem}

It should be noted that Article 58 of the Criminal Procedure Code of the Russian Federation, which regulates the attraction of a specialist for the participation in legal proceedings at the stages of pre-trial proceedings, is primarily focused, as indicated earlier in Article $133^{1}$ of the Criminal Procedure Code of the RSFSR, on the use of a specialist's knowledge and skills in the process of work with material sources of evidence (objects and documents), assistance in the use of technical means in the study of a criminal case materials, as well as for putting questions to an expert (Part 1, Article 58 of the Criminal Procedure Code of the Russian Federation) and does not allow extensive interpretation of a specialist's powers. In this regard, while supporting the opinion expressed

an investigative body or the court (Paragraphs 3, 4 of Article 80 of the Criminal Procedure Code of the Russian Federation).

4 On this and other procedural and forensic features of the use of specialised knowledge in Lithuanian criminal proceedings see the study by Professor Hendrik Malevski (Malevski, 2020: 414-430). in the legal literature about the possibility of expanding the functions of a specialist during interrogation and the possibility to empower a specialist to carry out a part of the interrogation that concerns raising questions aimed at supplementing, detailing and clarifying the testimony presented in the form of a free story, we cannot agree with the statement about the legitimacy of this approach (Ishchenko et al., 2014: 384).

The formal and logical interpretation of the provisions set out in Article 58 of the Criminal Procedure Code of the Russian Federation, despite a specialist's right to ask (with the permission of an investigator) questions to the participants of an investigative action, leads to the conclusion that a specialist's right to pose questions should not contradict the purpose of his/her involvement in an investigative action, which is limited to the first part of the aforementioned article. Empowering a specialist to carry out a part of interrogation should be regarded as a violation of the established procedure for conducting an investigative action.

The necessity for an extensive use of a specialist's specialised knowledge and skills in the process of interrogation and other non-verbal investigative actions requires introduction of the corresponding changes in the content of certain norms of the Criminal Procedure Code of the Russian Federation regulating the procedure for a specialist's participation in investigative actions.

\section{Discussion}

For the factual substantiation of this proposal, let us turn to the results of our survey of investigators who investigate mainly economic crimes. The survey was conducted in 2018. 56 investigators of the Main Investigation Department of the Investigative Committee for the Krasnoyarsk Krai (hereinafter - the IC investigators), and investigators of the Central Investigation Department of the Main Department of the Ministry of Internal Affairs for the Krasnoyarsk Krai (hereinafter - the MDMIA investigators) were surveyed. The average work experience of the surveyed employees in law enforcement agencies was almost 9 years (8.9 years, including the MDMIA investiga- 
tors -11.5 years and the IC investigators -6.6 years), which indicates an extensive experience of investigating criminal cases of this category. At the same time, the need to apply their own specialised knowledge or a specialist (expert)'s knowledge arises almost always - for 27 percent of the respondents.

Analysing the frequency of various forms of a specialist-economist participation in criminal cases investigation, the investigators set the following priorities (from 1 to 10: 1 - I do not use this form; 10 - I use it in the investigation of each criminal case): consultation with an expert before appointing a forensic examination - 9.02; initiation and carrying out forensic economic examination 8.87; interrogation of an expert - 7.47; obtaining a specialist's opinion - 7.23; initiation and carrying out audits - 6.79; involvement of a specialist into investigative and other procedural actions -6.22 ; consultations with specialists-economists while preparing for interrogation (of a suspect, accused, etc.) - 5.97; involving a specialist to assist in assessing an expert's opinion and interrogating an expert -
4.9; initiation and carrying out audits and tax inspections -4.72 .

The survey results clearly indicate that preparation for initiation, initiation, carrying out and assessment of the results of a forensic economic examination are, as a rule, in demand in almost every criminal case in connection with economic crimes. At the same time, an analysis of an issue of in which investigative actions it is reasonable and necessary to include the participation of a specialist-economist, in the opinion of the interviewed investigators, is of scientific interest. The respondents indicated several answer options (Fig. 1). As shown in Figure 1, a specialist's assistance is in high demand and necessary for an investigator in carrying out such investigative actions as inspection of objects and documents, interrogation of a suspect and accused (manager, chief accountant), as well as a search.

If we consider the indicators obtained in Figure 1 from the point of view of the mathematical Pareto distribution, it can be stated that participation of a specialist in three aforementioned investigative actions should provide

Investigative actions in which the participation of a specialist- economist is relevant and indispensable (findings of the survey)

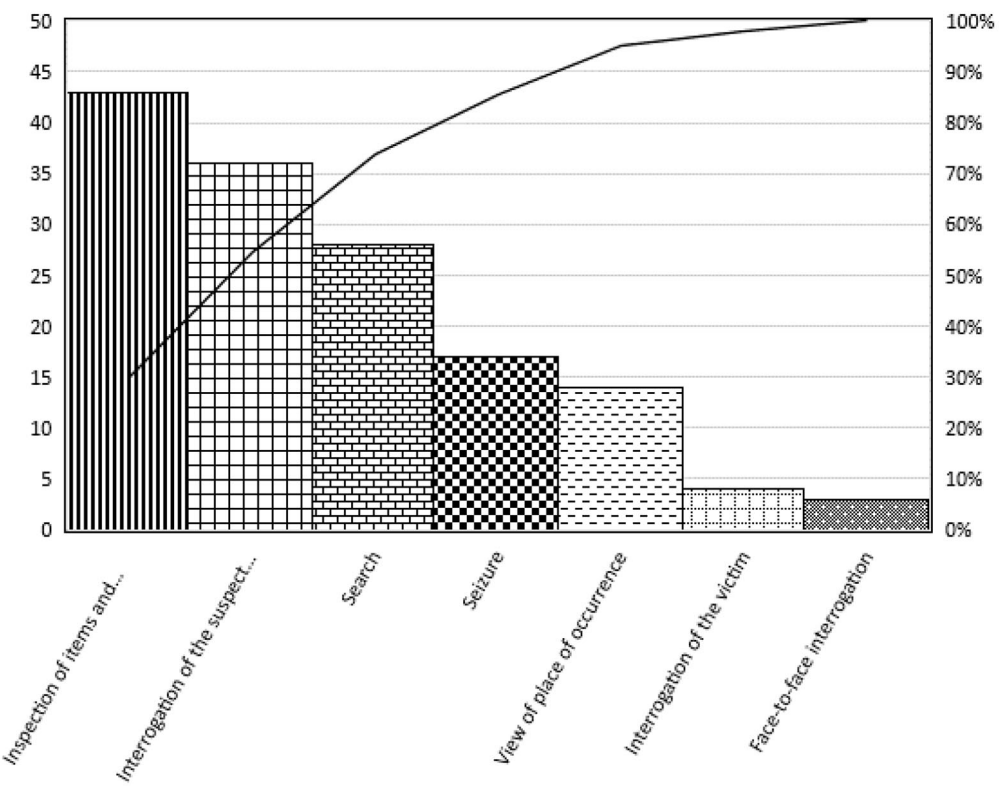

Fig. 1. Investigative actions in which the participation of a specialist-economist is reasonable and necessary (result of the survey of investigators) 
80 percent of the effectiveness and efficiency (collection of the necessary evidentiary information) of all investigative actions carried out in practice, for participation in which a specialist is involved. At the same time, according to the results of the survey of investigators about the actual investigative actions carried out in practice with the participation of a specialist (Fig. 2), most often a specialist is involved in the following actions: inspection of objects and documents (frequency of occurrence - 4.34; it was required to distribute points from 1 to 10 (1 - I never resort to a specialist's assistance; 10 - I resort to the participation of a specialist in this investigative action in the process of investigation of each criminal case), search (4.32), inspection of the scene of an accident (3.56), seizure (3.38), interrogation of a suspect or accused (2.65), interrogation of the victim (1.2).

Thus, the result of the survey of investigators has shown that reasonability, necessity and the need for the interrogation of a suspect (accused) with the participation of a specialist-economist is obvious.

Any person with specialised accounting and economic, forensic accounting and other knowledge in certain areas of the economy and finance can be invited for the participation in the interrogation as a specialist. In case of the economic sphere, private auditors, auditors of the Accounts Chamber of the Russian Federation or an economic agent of the Russian Federation, inspectors of the Federal Tax Service, employees of the Federal Treasury and other supervisory departments of the Ministry of Finance of the Russian Federation, specialists of municipal control bodies, employees of financial and accounting departments of organisations of different legal forms, employees of scientific research organisations, lecturers of accounting and economic disciplines of higher educational institutions; other persons with professional experience related to the field of economic and forensic accounting knowledge and the field of their practical application can be invited as specialists. At the same time, according to the investigative practice, in most cases an employee who is on the staff of the expert subdivision of a law enforcement agency is invited as a specialist. The investigators also noted that different specialists, depending on the required level and area of knowledge are involved in the investigation each time. It is

Investigative actions in the investigation of criminal cases in which a specialist-economist is involved

(frequency of occurrence from 1 to 10)

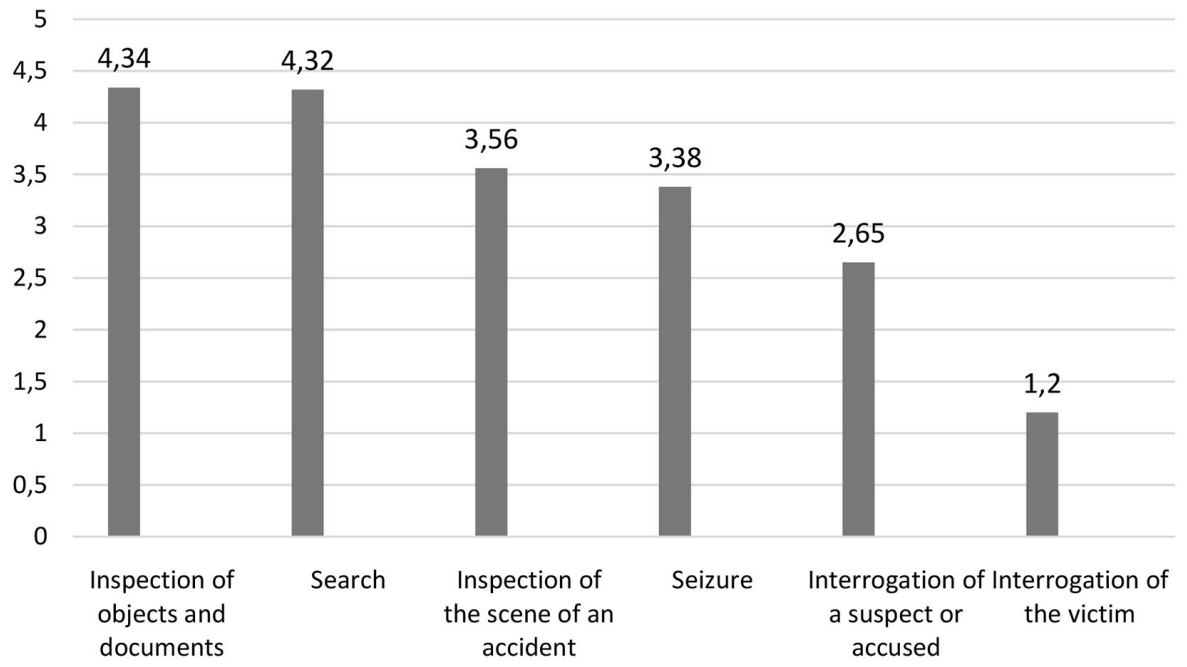

Fig. 2. Investigative actions in which a specialist-economist is involved, according to the results of the survey of investigators (frequency of occurrence from 1 to 10) 
necessary to pay attention the problem, identified by investigators, which consists in the fact that the reason for the limited involvement of economists-specialists for participation in investigative actions is the lack of such specialists on the staff of a law enforcement agency and, therefore, their assistance is rarely used.

Let us consider some of the features of an interrogation carried out with the participation of a specialist in cases connected with economic crimes. The target of such an interrogation is to establish the circumstances and the mechanism of committing a crime, as well as to establish the circumstances for finding evidence or which knowledge is necessary to verify and evaluate the evidence. Such circumstances, as a rule, are associated with the content of documents and other sources of accounting and economic information on financial and economic transactions that were seized at the stage of initiating a criminal case and during its investigation. It is the participation of a specialist in interrogation that can ensure the correct use and presentation of evidence-documents in the process of interrogation, the correct formulation of questions to a suspect (accused) and the accuracy of the record of his/her answers to the questions posed in the interrogation report.

In this way, when investigating tax crimes, I.V. Aleksandrov recommends interrogating a taxpayer with the participation of specialists in economic, accounting and tax fields. In his opinion, this approach can ensure the correctness of posing questions, the accuracy of their records in the report and the answers received to the questions posed (Aleksandrov, 2019: 260 ). This point of view concerns not only the investigation of tax, but also other types of crimes that require the use of specialised knowledge and skills.

During the interrogation of $I$. as a suspect in a criminal case initiated based on Part 1, Article 145.1 of the Criminal Code of the Russian Federation, carried out with the participation of an expert who had previously conducted a forensic economic examination on this case, the incoming cash documents, based on which the agent's fee was received, were shown to the suspect and his defender, and the expert asked about the reasons for the discrepancy between the numbers indicated in the cash receipts and the numbers indicated in the cash book for the period under study. Suspect I. explained that "the number of the document in the cash receipts was manually put by me and corresponds to the date of drawing up indicated in the receipt, since I do not have the skills in formalising such documents in the software "1C: Enterprise - LLC 'K"'. Later, accountant G. formalised these documents in the software with other serial numbers on the same dates, and these receipts were reflected in the cash book". Further, the expert demonstrates "1C: Enterprise - LLC 'K"' (with the databases of the organisation under investigation), submitted earlier for the examination to the interrogated I. and his defender, and the expert asks: could you, please, explain why the cash receipts shown to you earlier were not reflected in the database " $1 \mathrm{C}$ : Enterprise - LLC ' $\mathrm{K}$ "? The suspect could not answer this question, referring to the need to clarify this issue with accountants.

The similar algorithm for presenting documents and information of the software " $1 \mathrm{C}$ : Enterprise - LLC " $K$ " by an expert participating in the interrogation as a specialist, was applied during the interrogation of witnesses: the accountant of LLC "K" $\mathrm{E}$. and the accountant of LLC " $\mathrm{K}$ " T. In this way, the interrogations of the suspect and witnesses conducted with the participation of a specialist made it possible to detect a number of financial transactions of the organisation aimed at withdrawing cash from the organisation, which could be used to pay off backdated salaries.

The choice of a certain sequence of the questions asked, the accuracy of the questions posed and the answers received recorded in the report are of great importance, especially in proving the intent of a guilty person. In this regard, the role of a specialist participating in such an interrogation and in preparation for it is invaluable. Firstly, presentation of documents to an interrogated person in a certain sequence allows not only to find out the circumstances of the crime committed, but to obtain the necessary evidentiary information as well. The specialist's questions, asked to an interrogated person in a certain logical order, demonstrating 
a good knowledge of the specialised issues of the subject of interrogation to an interrogated person, allow an investigator to maintain contact with an interrogated person.

During the questionnaire survey, investigators were asked to substantiate the advantages of an interrogation conducted with the participation of a specialist, distributing points from 1 to 10 according to the degree of their significance $(1-$ this can hardly be called an advantage; 10 - I consider the participation of a specialist-economist extremely necessary for solving interrogation problems). The following results have been obtained:

1. The presentation of accounting documents by a specialist-economist during the interrogation and clarification of the circumstances of transactions in this regard reduces the possibility of false testimony by an interrogated person and allows to obtain new evidentiary information quickly -7.77 .

2. Participation of a specialist-economist in the interrogation (if an investigator has lack of knowledge in certain areas of specialised fields) reduces the possibility of false testimony regarding events and facts of economic activity by an interrogated person -7.34 .

3. By increasing a specialist's independence, an investigator does not lose his/her procedural duty to conduct interrogation. In terms of asking questions, he/she turns to a specialist only for assistance -6.21 .

4. In conditions when an investigator allows a specialist to ask questions during the interrogation, taking into account the testimony received, it becomes possible to promptly change the questions wording, specify the planned questions and add new ones -6.14 .

5. By entrusting a specialist to conduct a part of interrogation, an investigator gets an additional opportunity not only to record the question, but also an exact answer to it in the report -5.82 .

6. By entrusting a specialist to conduct a part of interrogation, an investigator gets an additional opportunity to establish and maintain the necessary contact with an interrogated person, including non-verbal one -4.77 .

It should be noted that interrogation of a suspect, an accused, or a witness, conducted with the participation of a specialist, requires careful preparation before its beginning. A written plan for such an interrogation should contain: firstly, the sequence of clarification of individual circumstances of financial and business transactions related to the crime; secondly, a list of documents presented to an interrogated person; thirdly, the necessary determination of the sequence of the questions asked, including those, asked by a specialist who takes part in the interrogation.

Tactically, it is of great importance to determine the optimal sequence of interrogations of suspects (accused) - heads of organisations and interrogations of witnesses - persons who are directly subordinate to the heads of organisations, counterparties, and officials of regulatory bodies (for instance, an inspector of the Federal Tax Service of the Russian Federation inspecting an organisation).

\section{Conclusion}

Let us formulate the main conclusions of the study:

1) an investigator cannot and should not have the entire set of specialised knowledge and skills in certain areas of activity. This gap can be filled by a specialist;

2) entrusting a specialist to conduct a part of interrogation, which involves posing questions and presenting evidence, an investigator does not lose procedural independence. In this part of interrogation, an investigator resorts to a specialist's assistance;

3) entrusting a specialist to conduct a part of interrogation, an investigator improves the quality and efficiency of an investigative action, excludes the demonstration of ignorance or misunderstanding of certain issues included in the subject of interrogation in front of an interrogated person who has specialised knowledge. Ignorance and lack of an investigator's preparation in certain issues does not contribute to the establishment and maintenance of contact interaction, which is extremely necessary and important for interrogation;

4) participation of a specialist in interrogation reduces the possibility of interested persons to give incomplete, inaccurate, as well as false testimony; 
5) wording, the sequence of asking questions, and presentation of evidence must be agreed upon before the start of interrogation, taking into account the specific features of the event under investigation, personality traits of an interrogated person and his/her procedural status;

6) in the process of posing questions and presenting evidence, taking into account the testimony received, a prompt (quick) reaction to the change of the content of subsequent questions, for which a specialist is more prepared than an investigator, may be required;

7) when entrusting a specialist to conduct a part of interrogation, an investigator not only has an additional opportunity to record the exact wording of the question, answers and explanations received regarding the evidence presented, but also provides an opportunity for more careful observation of an interrogated person's behaviour and reaction;

8) expanding the powers of a specialist in the process of interrogation makes it possible to prepare for the appointment of forensic examinations more fully and thoroughly.

Based on the formulated conclusions, it is proposed to expand the powers of an investigator and a specialist in the field of verbal investigative actions, including interroga- tion. In this regard, it is necessary to amend the wording of Article 38 and Article 58 of the Criminal Procedure Code of the Russian Federation. Paragraph 3, Part 2 of Article 38 of the Criminal Procedure Code of the Russian Federation, which establishes the powers of investigator, should be worded as follows: "To independently direct the course of investigation, to make decisions on the conduct of investigative and other procedural actions, seeking assistance from a specialist" ... (hereinafter in the text). Delete the phrase "in detection, consolidation and seizure of objects and documents" from Part 1 of Article 58 of the Criminal Procedure Code of the Russian Federation, and replace it with the phrase "in evidence collection", which is used in Article 86 of the Criminal Procedure Code of the Russian Federation and is broader in its meaning than the phrase "detection, consolidation and seizure of objects and documents". The proposed changes, in our opinion, will significantly expand the powers of a specialist in the course of all investigative actions (including verbal ones) and will correspond to modern trends in the development of criminal proceedings, increasing its quality by attracting specialised knowledge and skills from various fields of human activity.

\section{References}

Aleksandrov, I.V. (2019). Nalogovye prestupleniia: rassledovanie: monografiia [Tax Crimes: Investigations: Monograph]. M., Iustitsiia, 286 p.

Beulke, W. (2004). Ugolovno-protsessual'noe pravo FRG [Criminal Procedure Law of the FRG] (translated from German by Ya.M. Ploshkina). Krasnoysrsk, Krasnoyarsk State Pedagogical University, $351 \mathrm{p}$.

Friis, E. \& Åström, K. (2017). The Use of Court-and Party-Appointed Experts in Legal Proceedings in Sweden: Judges' Experiences and Attitudes. Oslo Law Review, 4 (2), 63-81.

Ishchenko, E.P., Egorov, N.N. (2014). Kriminalistika dlia sledovatelei i doznavatelei: nauchno-prakticheskoe posobie [Forensic Science for Investigators and Interrogators: A Scientific and Practical Guide], $2^{\text {nd }}$ edition, revised and corrected. M., Yuridicheskaia firma “KONTRAKT": INFRA-M. 699 p.

Kurs ugolovnogo protsessa [The Course of Criminal Procedure] (2017). Ed. by Doctor of Law, Prof. L.V. Golovko, $2^{\text {nd }}$ edition, revised. M., Statut. 1280 p.

Malevski, H. (2020). Ugolovno-protsessual'naia deiatel'nost' spetsialista v Litovskoi Respublike v kontekste mezhdunarodnogo sotrudnichestva [Criminal Procedure of a Specialist in The Republic of Lithuania in The Context of International Cooperation], In Vestnik of Saint Petersburg University. Law. 11(2), 414-430.

Narang, S.K., Paul, S.R. (2017). Expert Witness Participation in Civil and Criminal Proceedings. Pediatrics. 139(3). Available at: https://pediatrics.aappublications.org/content/139/3/e20164122 
Nogel, M. (2019). Expert Evidence in Criminal Proceedings in Hungary, In Zbornik z medzinárodnej vedeckej konferencie Bratislavské právnické fórum [Collection of Works from The Bratislava Legal Forum 2019], 20-29.

Shepherd, J.P. (1993). Presenting Expert Evidence in Criminal Proceedings, In The BMJ (British Medical Journal), 307, 817-818.

Smyk, R.K. (1979). Vozmozhnosti ispol'zovaniia spetsial'nykh poznanii pri rassledovanii prestuplenii: sledstvennaia praktika [Possibilities of Using Specialised Knowledge in Crimes Investigation: Investigative Practice]. M., Yuridicheskaia literatura, 121, 32-39.

Ugolovnyi protsess Rossii. Osobennaia chast': Uchebnik [Criminal Procedure in Russia. Special Part: Coursebook] (2005). Ed. by V.Z. Lukashevich. SPb., Publishing House of Saint Petersburg State University. $704 \mathrm{p}$.

Ustav Ugolovnogo sudoproizvodstva [Statute of Criminal Procedure] (1911). Authors M.P. Shramchenko and V.P. Shirkov. $5^{\text {th }}$ Edition revised and corrected, Saint Petersburg. 1264 p.

\title{
Расширение полномочий специалиста в досудебном производстве - необходимое условие повышения качества производства следственных действий, направленных на получение показаний
}

\author{
А.И. Баянов \\ ${ }^{a}$ Сибирский федеральный университет \\ Российская Федераичия, Красноярск \\ ${ }^{6}$ Санкт-Петербургский государственный университет \\ Российская Федерачия, Санкт-Петербург
}

\begin{abstract}
Аннотация. На основе анализа отечественного исторического опыта и современного состояния законодательного регулирования привлечения специалиста для оказания содействия следователю при проведении следственных действий, а также проведенного опроса следователей сделан вывод о необходимости расширения полномочий специалиста в части оказания содействия следователю при проведении следственных действий, направленных на получение показаний (в том числе допроса). В связи с этим внесены предложения по изменению редакции статей 38 и 58 УПК РФ. Предлагаемые изменения существенно расширят полномочия специалиста при производстве всех следственных действий (в том числе вербальных) и будут соответствовать современным тенденциям в развитии уголовного судопроизводства, повышая его качество посредством привлечения специальных знаний и навыков из различных областей человеческой деятельности.
\end{abstract}

Ключевые слова: следственное действие, следователь, специалист, собирание доказательств, содействие следователю.

Научная специальность: 12.00.09 - уголовный процесс. 